\title{
Sosialisasi dan Pelaksanaan Senam Hamil di Rumah Bersalin Citra Lestari Bogor
}

\author{
Triana Indrayani*, Risza Choirunnisa \\ Fakultas Ilmu Kesehatan, Universitas Nasional, Indonesia \\ * triana.civitas.unas@gmail.com
}

\begin{abstract}
ABSTRAK
Keberhasilan pembangunan kesehatan sesuai dengan tujuan dari pembangunan millennium yang menetapkan tahun 2015 sebagai batas waktu pencapaian target-target, tujuan dari Millenium Development Golds (MDGs). Dari delapan tujuan tersebut ada tujuan yang membahas tentang angka kematian anak dan meningkatkan kesehatan ibu. Menurut hasil penelitian sekitar 70\% dari ibu hamil mengalami sakit pinggang Low Back Pain (LBP) yang mungkin dimulai sejak awal trimester, puncak kejadian LBP terjadi pada trimester II dan III kehamilan dan intensitas nyeri memburuk dengan kehamilan berisiko. Salah satu cara mengatasi permasalahan pada ibu hamil tersebut yaitu dengan melakukan senam hamil. Metode yang digunakan adalah ceramah, praktik dan tanya jawab. Hasil dari kegiatan ini semua peserta sangat tertib mendengarkan paparan materi dan antusias saat bertanya maupun menjawab pertanyaan dan mereka mengatakan kegiatan ini sangat bermanfaat untuk meningkatkan pengetahuan mereka dalam mengatasi masalah yang terjadi pada kehamilan.
\end{abstract}

Kata Kunci: Sosialisasi, Senam Hamil, Pengabdian Masyarakat

This is an open-acces article distributed under the terms of the Creative Commons Attribution-ShareAlike 4.0 International License.

\section{PENDAHULUAN}

Keberhasilan pembangunan kesehatan sesuai dengan tujuan dari pembangunan millennium yang menetapkan tahun 2015 sebagai batas waktu pencapaian target-target, tujuan dari Millenium Development Golds (MDGs). Dari delapan tujuan tersebut ada tujuan yang membahas tentang angka kematian anak dan meningkatkan kesehatan ibu yaitu masuk dalam tujuan keempat dan kelima.Diantara prediktor kondisi kesehatan di Indonesia, tingkat kematian ibu dapat dikatakan paling memprihatinkan. Angka Kematian Ibu (AKI) 307 kematian per 100.000 kelahiran hidup pada SDKI 2002-2003.

Angka kematian ibu melahirkan tidak mengalami penurunan dalam 5 tahun terakhir. Target Millennium Development Goals (MDG's) tahun 2016 AKI menjadi 100 kematian per 100.000 kelahiran hidup. Kematian ibu dapat dicegah hingga $22 \%$ yaitu melalui antenatal care yang teratur, mendeteksi dini adanya komplikasi dalam kehamilan, hidup sehat dengan pemenuhan gizi yang seimbang, pelaksanaan inisiasi menyusui dini dalam persalinan, serta pelaksanaan senam hamil secara teratur. Salah satu kegiatan dalam pelayanan selama kehamilan yang bertujuan untuk mempersiapkan fisik dan mental ibu 


\section{Journal of Community Engagement in Health}

hamil adalah senam hamil. Sangat penting bagi wanita untuk mempertahankan atau memperbaiki kondisi fisiknya bila ia ingin kehamilan yang terbaik dan untuk menghadapi stress yang dialami tubuhnya karena perkembangan janin. Penyebab kematian ibu tersebut karena kehamilan atau persalinan yang disebabkan oleh aspek medis, sosial, budaya dan agama. Salah satu aspek medis tersebut yaitu persalinan dengan komplikasi.

Komplikasi dalam kehamilan seperti kehamilan ektopik, hiperemesis gravidarum, abortus, eklamsia, plasenta previa yang sangat mengancam nyawa ibu hamil. Dalam mengatasi penyebab masalah tersebut diperlukan pendekatan yang berkualitas yang dimulai sejak perencanaan kehamilan dan selama masa kehamilan.

Selama masa kehamilan ibu hamil mengalami perubahan fisik dan psikologis yang dapat menimbulkan ketidaknyamanan terutama pada trimester III seperti dispnea, insomnia, gingivitis dan epulis, sering buang air kecil, tekanan dan ketidaknyamanan pada perineum, nyeri punggung, konstipasi, varises, mudah lelah, kontraksi braxton hicks, kram kaki, edema pergelangan kaki dan perubahan mood serta peningkatan kecemasan.

Pada umumnya wanita yang sedang hamil takut menghadapi proses persalinan karena rasa sakit yang menimbulkan rasa takut dan cemas. Hal ini dapat menimbulkan ketegangan jiwa dan fisik yang akan mengakibatkan kakunya otot-otot dan persendian yang tidak wajar. Stres atau kecemasan tersebut terkait dengan berbagai hasil kehamilan, rasa sakit dan keluhan somatik lain yang sering terjadi dengan gangguan mood pada ibu hamil.

Menurut hasil penelitian sekitar $70 \%$ dari ibu hamil mengalami sakit pinggang Low Back Pain (LBP) yang mungkin dimulai sejak awal trimester, puncak kejadian LBP terjadi pada trimester II dan III kehamilan dan intensitas nyeri memburuk dengan kehamilan berisiko. Gangguan psikologis pada ibu hamil juga dapat berpengaruh buruk terhadap perkembangan janin. Pada ibu hamil yang mengalami stress yang berkepanjangan dapat menimbukan hambatan perkembangan pada janin termasuk gangguan emosi setelah kelahiran, bila stress pada ibu tidak tertangani dengan baik meskipun dengan asupan nutrisi yang baik. Gangguan psikologis tersebut dapat meningkatkan resiko terjadinya komplikasi dalam persalinan sehingga diperlukan pencegahan dengan beberapa metode untuk meringankan dan mempersiapkan ibu dalam menjaga kehamilan dan proses persalinannya.

Pencegahan komplikasi persalinan bertujuan untuk membuat ibu dan bayi baru lahir dapat memperoleh derajat kesehatan yang tinggi dan terhindar ancaman atau fungsi reproduksi. Bidan diakui sebagai tenaga profesional yang bertanggung jawab dan akuntabel, yang bekerja sebagai mitra perempuan untuk memberikan dukungan, asuhan dan nasehat selama masa hamil. Asuhan yang mencakup upaya pencegahan, promosi persalinan normal, deteksi komplikasi pada ibu dan anak, dan akses bantuan medis atau bantuan lain yang sesuai, serta melaksanakan tindakan kegawat-daruratan.

Bidan mempunyai tugas penting dalam konseling dan pendidikan kesehatan, tidak hanya kepada perempuan, tetapi juga kepada keluarga dan masyarakat. Salah satu kegiatannya adalah mencakup pendidikan antenatal. Salah satu intervensi yang dapat dilakukan adalah latihan fisik, sebab berpengaruh positif terhadap janin, kehamilan, berat lahir dan kesehatan maternal serta mengurangi komplikasi persalinan seperti persalinan lama dan menurunkan tingkat nyeri. Latihan fisik yang dapat dilakukan selama masa kehamilan salah satunya adalah senam hamil.

Senam hamil selama kehamilan dapat meningkatkan berat lahir dan mengurangi kejadian prematur dan komplikasi persalinan menurut Narendran (2009) di Bangalore. Sedangkan manfaat dari senam hamil secara teratur sangat membantu dalam menjaga kesehatan dan kelancaran proses persalinan dan nifas sebab senam hamil akan membuat 


\section{Journal of Community Engagement in Health}

http://jceh.org

ISSN: 2620-3758 (print); 2620-3766 (online)

https://doi.org/10.30994/jceh.v3i2.55

Vol.3 No.2. Sep 2020. Page.158-162

tubuh menjadi lentur terutama pada otot-otot jalan lahir. Kelenturan otot ini sangat diperlukan karena karena saat menghadapi persalinan ibu biasanya dilanda kecemasan dan panik. Selanjutnya keadaan ini membuat otot menjadi tegang.

\section{METODE}

Kegiatan pengabdian masyarakat ini dilakukan atas dasar untuk mengatasi berbagai keluhan yang dihadapi pada ibu hamil khususnya ibu hamil trimester 3.

Langkah-langkah yang dilakukan dalam kegiatan ini :

1. Lokasi Pengabdian

Pemilihan lokasi pelaksanaan Pengabdian Kepada Masyarakat ditentukan berdasakan pada kepentingan aktual, yaitu di Rumah Bersalin Citra Lestari Bogor dimana ditempat ini banyak terdapat pasien ibu hamil yang rutin melakukan pemeriksaan kehamilan namun belum memiliki pengetahuan tentang manfaat dari senam hamil.

2. Instrumen untuk Pelaksanaan Kegiatan
a. Alat presentasi (Lap Top, LCD).
b. Makalah/brosur
c. Spanduk
d. Kamera
e. Matras Senam
f. Sound sistem
g. ATK dan Formulir
h. Daftar Hadir
i. Alat tulis

3. Jadwal Kegiatan

\begin{tabular}{|l|l|l|l|l|}
\hline No. & Uraian Kegiatan & Maret & April & Mei \\
\hline 1. & $\begin{array}{l}\text { Pengurusan } \\
\text { perijinan }\end{array}$ & $\mathrm{x}$ & & \\
\hline 2. & $\begin{array}{l}\text { Persiapan } \\
\text { pelaksanaan }\end{array}$ & $\mathrm{x}$ & $\mathrm{x}$ & \\
\hline 3. & $\begin{array}{l}\text { Pelaksanaan } \\
\text { penyuluhan }\end{array}$ & & & $\mathrm{x}$ \\
\hline 4. & Pembuatan laporan & & & \\
\hline
\end{tabular}

Keterangan :

1. Pengurusan perijinan kepada ke tempat pelaksanaan dengan tujuan untuk kelancaran pelaksanaan pengabdian.

2. Persiapan pelaksanaan, meliputi persiapan materi penyuluhan, pemantapan materi penyuluhan dan kelengkapan pendukung penyuluhan.

3. Pelaksanaan pengabdian dilakukan di lokasi yang telah ditentukan.

Metode yang digunakan dalam penyampaian materi :
a. Ceramah
Ceramah adalah penyajian informasi secara lisan baik formal maupun informal oleh pemateri
b. Praktik Senam
Melakukan senam hamil sesuai gerakan yang ada di leaflet
c. Tanya Jawab 
Tanya Jawab adalah metode mengajar yang memungkinkan terjadinya komunikasi langsung yang bersifat two way traffic sebab pada saat yang sama terjadi dialog antara pemateri dan penerima materi. Sesi Tanya jawab ini digunakan untuk mengulang kembali materi yang sudah diberikan.

d. Doorprize

Sesi doorprize ini sekaligus digunakan untuk melakukan evaluasi terhadap kegiatan pengabdian masyarakat ini, 3 pertanyaan telah disiapkan dengan 3 hadiah bagi peserta yang dapat menjawab pertanyaan.

4. Pembuatan laporan dilakukan oleh Tim setelah selesai pelaksanaan pengabdian.

\section{HASIL DAN PEMBAHASAN}

Sosialisasi dan pelaksanaan senam hamil dilakukan disesuaikan dengan umur kehamilan trimester 3 awal dan trimester 3 akhir. Pelaksanaan senam hamil ini dipandu oleh 2 instruktur. Sebelum praktik senam hamil terlebih dahulu ibu hamil diberikan penjelasan tentang manfaat dan gerakan-gerakan yang ada pada senam hamil.

Selama 25 menit pemberian materi senam hamil dilanjutkan dengan sesi Tanya jawab, dari tiga pertanyaan yang diberikan semua dapat dijawab oleh peserta. Sesi door prize pun diikuti dengan baik terbukti dengan peserta dapat memberikan resume dari paparan materi tentang senam hamil. Hasil dari kegiatan ini semua peserta sangat tertib mendengarkan paparan materi dan antusias saat bertanya maupun menjawab pertanyaan dan mereka mengatakan kegiatan ini sangat bermanfaat untuk meningkatkan pengetahuan mereka dalam mengatasi masalah yang terjadi pada kehamilan.

\section{KESIMPULAN DAN SARAN}

\section{a. Kesimpulan}

Sosialisasi dan pelaksanaan senam hamil dilakukan di lantai 1 dan 2, dengan 2 instruktur, untuk ibu hamil trimester 3 awal dan trimester 3 akhir kunjungan dipisahkan tempatnya, peserta mengatakan banyak manfaat dari adanya senam hamil khususnya untuk mengurangi sakit pinggang dan mereka mengatakan akan melakukan senam hamil secara rutin sesuai jadwal yang sudah ditentukan dan mereka sangat antusias dengan adanya pembagian leaflet, terbukti mereka minta leaflet lebih dari 1 dengan alasan akan dibagikan ke tetangga atau teman mereka yang sedang hamil .

b. Saran

\section{Saran untuk ibu hamil}

Untuk ibu hamil disarankan agar teratur dalam mengikuti kegiatan senam hamil agar keluhan-keluhan selama kehamilan seperti nyeri pinggang dapat berkurang dan kondisi fisik menjelang persalinan juga tetap terjaga.

\section{Saran untuk tempat pengabdian masyarakat}

Untuk tempat pengabdian masyarakat disarankan untuk meningkatkan promosi kesehatan khususnya tentang senam hamil baik melalui poster, leaflet maupun video yang dapat ditampilkan melalui layar LCD yang ada di ruang tunggu.

\section{UCAPAN TERIMAKASIH}

Ucapan terimakasih penulis sampaikan pada Wakil Rektor Bidang Penelitian, Pengabdian Masyarakat dan Kerjasama (PPMK) Universitas Nasional dan Rumah Bersalin Citra Lestari yang sudah membantu dan memfasilitasi kegiatan pengabdian masyarakat ini. 


\section{DAFTAR PUSTAKA}

Kementrian Kesehatan Republik Indonesia Tahun 2014, Pedoman pelaksanaan kelas ibu hamil

Gerakan Senam Hamil pada Kehamilan Trimester Ketiga| Popmama.com

PANDUAN-LATIHAN-FISIK-BUMIL-DEPKES.pdf

Pengaruh Kombinasi Prenatal Yoga dan Senam Hamil Terhadap Tingkat Kecemasan dan Lama Persalinan Kala I pada Ibu Hamil Trimester III

Anik Maryunani, S.Kep, Ns, ETN, RN, Buku Buku Senam Hamil Senam Nifas dan Terapi Musik 